\title{
Properties and Plasticity of Excitatory Synapses on Dopaminergic and GABAergic Cells in the Ventral Tegmental Area
}

\author{
Antonello Bonci ${ }^{1}$ and Robert C. Malenka ${ }^{1,2}$ \\ Departments of ${ }^{1}$ Psychiatry and ${ }^{2}$ Physiology, University of California, San Francisco, California 94143
}

\begin{abstract}
Excitatory inputs to the ventral tegmental area (VTA) influence the activity of both dopaminergic (DA) and GABAergic (GABA) cells, yet little is known about the basic properties of excitatory synapses on these two cell types. Using a midbrain slice preparation and whole-cell recording techniques, we found that excitatory synapses on DA and GABA cells display several differences. Synapses on DA cells exhibit a depression in response to repetitive activation, are minimally affected by the $\mathrm{GABA}_{\mathrm{B}}$ receptor agonist baclofen, and express NMDA receptor-dependent long-term potentiation (LTP). In contrast, synapses on GABA cells exhibit a facilitation in response to repetitive activation, are depressed significantly by baclofen,
\end{abstract}

The ventral tegmental area (VTA) is a critical component of the neural system that is thought to underlie natural reinforcement as well as the reinforcing properties of drugs of abuse (Robbins and Everitt, 1996; Wise, 1996; Koob and LeMoal, 1997). It contains two major cell types: primary dopaminergic neurons, the axon terminals of which release dopamine (DA) in target areas such as the nucleus accumbens and prefrontal cortex, and secondary neurons, the majority of which are GABAergic (GABA) and thus function as local interneurons to control the firing of the principal DA neurons (Johnson and North, 1992; Kalivas, 1993; White, 1996; Overton and Clark, 1997). Recent work has confirmed that most VTA non-DA cells are indeed GABAergic and that, in addition to providing inhibitory inputs to VTA DA cells, they send axon projections to cortex (Van Bockstaele and Pickel, 1995; Steffensen et al., 1998).

The firing of VTA DA neurons is thought to reflect information about the rewarding or motivationally relevant properties of external stimuli (White, 1996; Overton and Clark, 1997; Schultz, 1998). An important factor controlling VTA DA cell firing is the direct input from prefrontal cortex (Kalivas, 1993; White, 1996; Overton and Clark, 1997), which forms excitatory synapses on both DA and GABA cells (Christie et al., 1985; Sesack and Pickel, 1992). Both cell types express NMDA and non-NMDA glutamate receptors (Kalivas et al., 1989; Seutin et al., 1990; Wang and French, 1993, 1995) that contribute to the generation of synaptic responses (Mereu et al., 1991; Johnson and North, 1992; White, 1996; Overton and Clark, 1997; Steffensen et al., 1998). However, the relative contributions of NMDA and non-

\footnotetext{
Received Jan. 13, 1999; revised Feb. 26, 1999; accepted March 4, 1999.

R.C.M. is supported by grants from National Institutes of Health and an Investigator Award from the McKnight Endowment Fund for Neuroscience. We thank members of the Malenka and Nicoll labs for many useful comments and discussions during the course of these experiments.

Correspondence should be addressed to Dr. Robert Malenka, Department of Psychiatry, LPPI, Box 0984, University of California, San Francisco, CA 94143. Copyright (C) 1999 Society for Neuroscience $0270-6474 / 99 / 193723-08 \$ 05.00 / 0$
}

and do not express LTP. The relative contribution of NMDA and non-NMDA receptors to the synaptic currents recorded from the two cell types is the same as is the depression of synaptic transmission elicited by the application of adenosine, serotonin, or methionine enkephalin (met-enkephalin). The significant differences in the manner in which excitatory synaptic inputs to DA and GABA cells in the VTA can be modulated have potentially important implications for understanding the behavior of VTA neurons during normal behavior and during pathological states such as addiction.

Key words: midbrain; ventral tegmental area; dopamine; synaptic plasticity; long-term potentiation; addiction
NMDA receptors to excitatory synaptic transmission on the two cell types have not been examined nor have several other of the basic properties of these synapses, such as their responses to repetitive stimulation or their modulation by presynaptic receptor agonists. That important functional differences may exist is suggested by recent work in the hippocampus (Maccaferri et al., 1998; Scanziani et al., 1998) and cortex (Markram et al., 1998; Reyes et al., 1998), which has demonstrated that excitatory synapses formed by the same axon on different postsynaptic targets can have profoundly different properties.

In addition to influencing the normal functioning of VTA cells, the prefrontal excitatory afferent input to the VTA is important for the development of behavioral sensitization to psychostimulants (for review, see Wolf, 1998), a model for the intensification of drug craving that contributes to drug addiction (Robinson and Berridge, 1993). Because behavioral sensitization and long-term potentiation (LTP) share several features, it has been suggested that synaptic plasticity at excitatory synapses on VTA DA neurons may be critically important for triggering this behavioral change (Karler et al., 1991; Schenk and Snow, 1994; Clark and Overton, 1998; Wolf, 1998). Thus, in addition to examining the basic properties of excitatory synapses on VTA DA and non-DA cells, we determined whether these synapses could generate LTP. Given the distinct functional roles of DA and GABA cells in the VTA, differences in the properties of their excitatory synapses should have important implications for the understanding of the role of the VTA in normal and pathological behavior such as drug dependence and addiction.

\section{MATERIALS AND METHODS}

Slice preparation. The preparation of VTA slices was as described previously (Cameron and Williams, 1994). Briefly, Sprague Dawley rats (14-42 d) were anesthetized with halothane and killed. A block of tissue containing the midbrain was sliced in the horizontal plane $(190-250 \mu \mathrm{m})$ with a vibratome (Leica, Nussloch, Germany). Slices (two to three per animal) were placed in a holding chamber and allowed to recover for at 

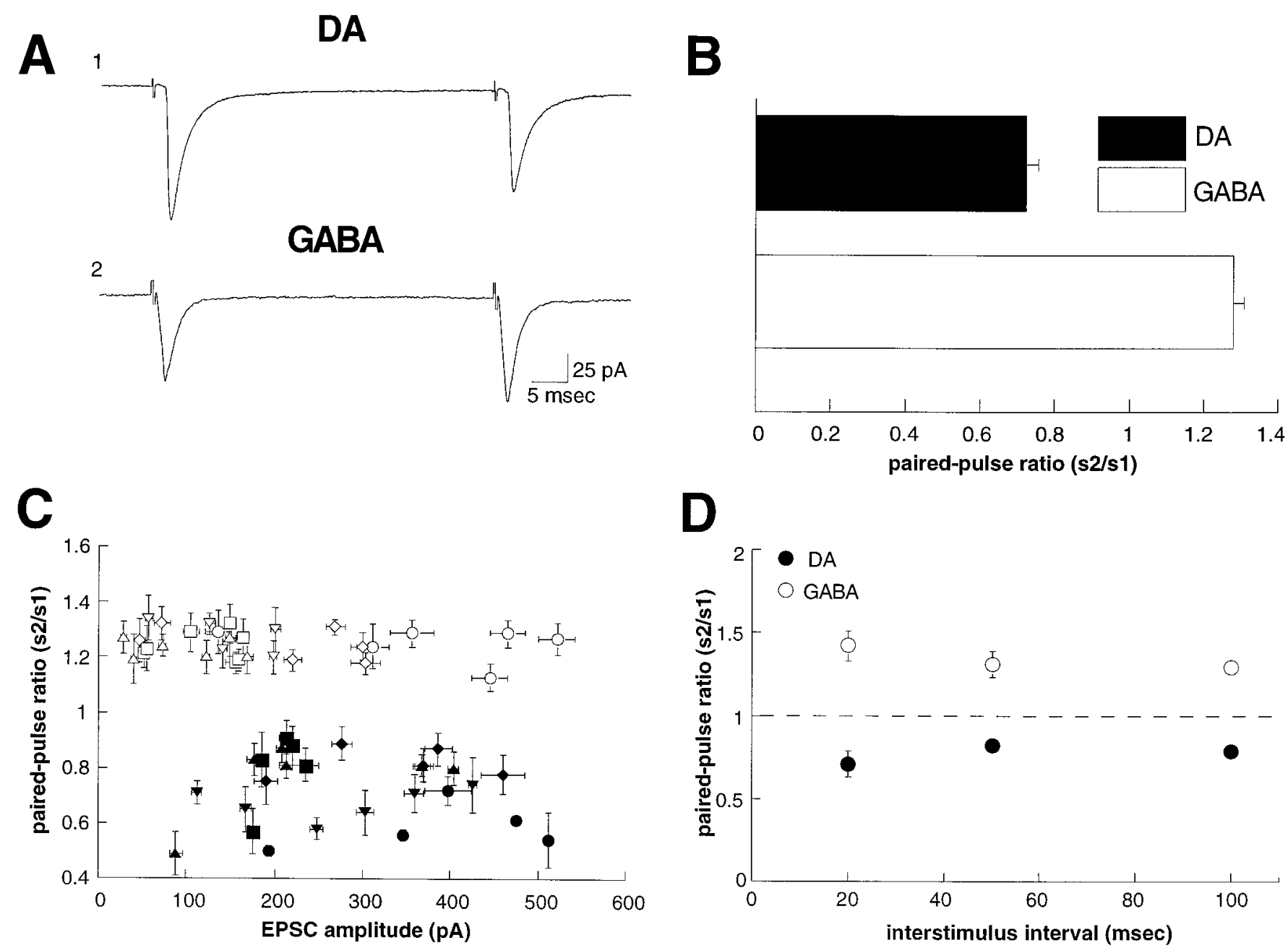

D

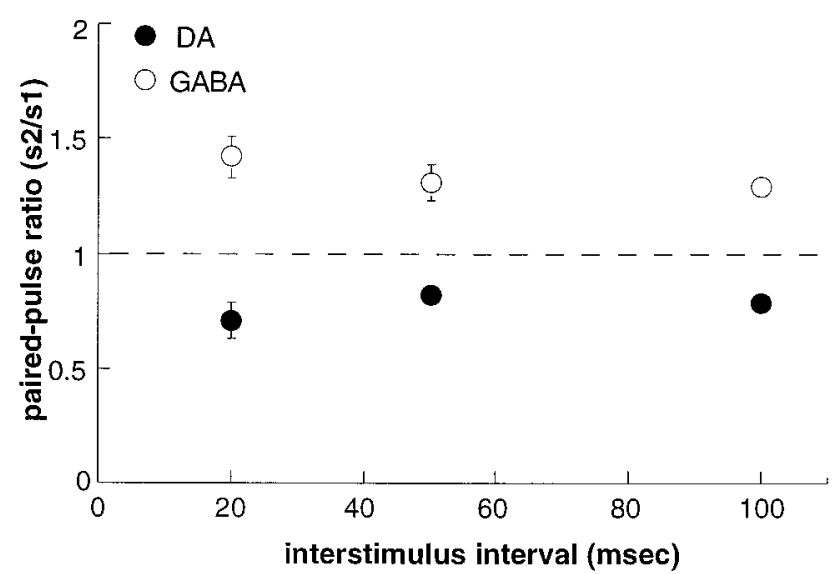

Figure 1. Dopaminergic $(D A)$ neurons display paired-pulse depression, whereas GABAergic $(G A B A)$ neurons show paired-pulse facilitation. $A$, Sample EPSCs in response to paired stimuli $\left(50 \mathrm{msec}\right.$ interstimulus interval) for a DA $\left(A_{1}\right)$ and GABA $\left(A_{2}\right)$ neuron (traces are the average of 20 consecutive sweeps). $B$, Average of the paired-pulse ratio for DA $(n=9)$ and GABA $(n=12)$ neurons. $C$, Graph of the paired-pulse ratio as a function of the first EPSC amplitude. The amount of paired-pulse facilitation or depression is independent of the amplitude of the EPSC. Each symbol represents a distinct cell. $D$, The paired-pulse ratio for DA and GABA neurons as a function of interstimulus interval.

least $1 \mathrm{hr}$ before being placed in the recording chamber and superfused with a bicarbonate buffered solution $\left(32-34^{\circ} \mathrm{C}\right)$ saturated with $95 \% \mathrm{O}_{2} /$ $5 \% \mathrm{CO}_{2}$ and containing (in mM): $126 \mathrm{NaCl}, 1.6 \mathrm{KCl}, 1.2 \mathrm{NaH}_{2} \mathrm{PO}_{4}, 1.2$ $\mathrm{MgCl}_{2}, 2.5 \mathrm{CaCl}_{2}, 18 \mathrm{NaHCO}_{3}$, and 11 glucose.

Whole-cell recording. Cells were visualized with an upright microscope with infrared illumination, and whole-cell voltage-clamp recordings were made by using an Axopatch 2D amplifier (Axon Instruments, Foster City, CA). Electrodes (3-8 M $\Omega$ ) contained (in mM): 117 cesium gluconate, 2.8 $\mathrm{NaCl}, 20 \mathrm{HEPES}, 0.4$ EGTA, 5 TEA-Cl, 2.5 MgATP, and 0.25 MgGTP, pH 7.3-7.4 (285-295 mOsm). For perforated patch recordings (Rae et al., 1991) the electrodes $(2-5 \mathrm{M} \Omega$ ) were filled with a solution containing (in $\mathrm{mm}$ ): 117 cesium gluconate, $2.8 \mathrm{NaCl}, 20 \mathrm{HEPES}, 0.4$ EGTA, and 5 TEA-Cl (pH 7.2 with CsOH, 285-295 mOsm). Amphotericin B (1.2 $\mathrm{mg} / \mathrm{ml}$; Sigma, St. Louis, MO) dissolved in DMSO (0.6\% final concentration) was added to this solution, triturated, and used to backfill pipettes. Experiments were begun only after series resistance had stabilized (typically 15-40 M $\Omega$ ). Series resistance and input resistance were monitored continuously on-line with a $4 \mathrm{mV}$ depolarizing step $(25 \mathrm{msec})$, which was given with every afferent stimulus. Data were filtered at 2 $\mathrm{KHz}$, digitized at $10 \mathrm{KHz}$, and collected on-line with acquisition software developed in this laboratory by D. Selig.

DA and non-DA cells were identified by the presence or absence, respectively, of a large $I_{\mathrm{h}}$ current (Johnson and North, 1992) that was assayed immediately after break-in, using a series of incremental $10 \mathrm{mV}$ hyperpolarizing steps from a holding potential of $-70 \mathrm{mV}$. A bipolar stainless steel stimulating electrode was placed $100-300 \mu \mathrm{m}$ rostral to the recording electrode and was used to stimulate excitatory afferents at 0.1
$\mathrm{Hz}$. Neurons were voltage-clamped at a membrane potential of $-70 \mathrm{mV}$, except where noted. All EPSCs were recorded in the presence of picrotoxin $(100 \mu \mathrm{M})$. The amplitudes of EPSCs were calculated by taking the mean of a 2-3 msec window around the peak and comparing this with the mean of a $10 \mathrm{msec}$ window immediately before the stimulation artifact.

Drugs were added to the superfusing medium at known concentrations immediately before application to the slice. D-APV [D(-)-2-amino-5phosphonopentanoic acid], CNQX (6-cyano-7-nitroquinoxaline-2,3dione), and MCPG [(RS)- $\alpha$-methyl-3-carboxy-4-hydroxyphenylglycine] were obtained from Tocris (Ballwin, MO). Picrotoxin and methionine enkephalin (met-enkephalin) were obtained from Sigma. Serotonin, baclofen, and adenosine were obtained from Research Biochemicals (Natick, MA). Results in the text and figures are presented as the mean \pm SEM. We considered $p<0.05$ statistically significant.

\section{RESULTS}

The results of this study are based on recordings made from 54 DA cells and 41 GABA cells that were identified by the presence or absence, respectively, of a prominent hyperpolarizationinduced inward current $\left(I_{\mathrm{h}}\right)$ (Johnson and North, 1992).

\section{Excitatory synapses on DA and GABA cells respond differently to repetitive stimulation}

In other brain regions it has been found that the excitatory synapses made by the same axon onto different target cells can 

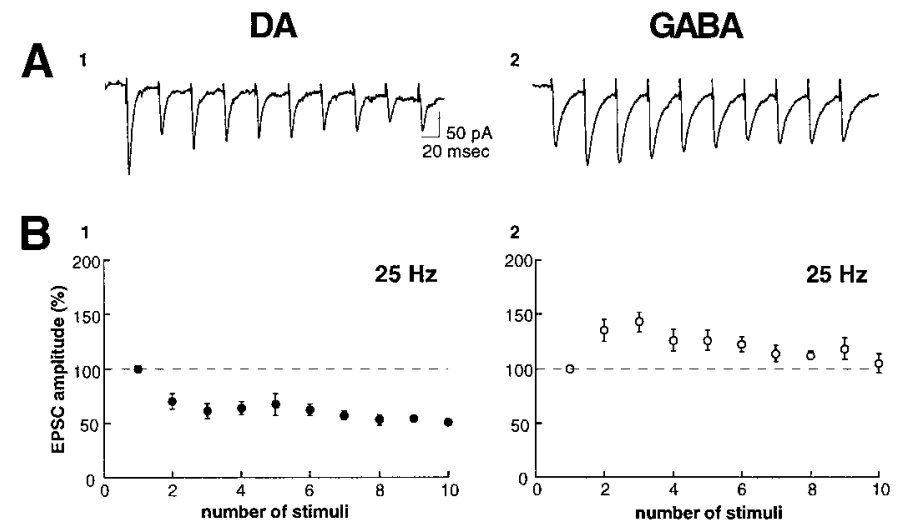

Figure 2. Repetitive stimulation produces a depression in DA neurons and a facilitation in GABA neurons. $A$, Sample EPSCs in response to 10 stimuli at $25 \mathrm{~Hz}$ for a DA $\left(A_{1}\right)$ and GABA $\left(A_{2}\right)$ neuron (traces are the average of 10 consecutive episodes). $B$, Graphs show the changes in EPSC amplitude during the 10 pulse train for DA $\left(B_{1}, n=5\right)$ and GABA neurons $\left(B_{2}, n=5\right)$.

differ significantly in their responses to repetitive stimulation (Maccaferri et al., 1998; Markram et al., 1998; Reyes et al., 1998; Scanziani et al., 1998). Therefore, in our first set of experiments we compared this property of the excitatory synapses on DA and GABA cells. Figure 1, $A$ and $B$, shows that the change in synaptic strength elicited by paired stimuli given at an interval of $50 \mathrm{msec}$ was significantly different for synapses on DA versus GABA cells. Synapses on DA cells exhibited a paired-pulse depression (s2/s1 ratio $=0.68 \pm 0.03 ; n=9$ ), whereas synapses on GABA cells exhibited paired-pulse facilitation $(\mathrm{s} 2 / \mathrm{s} 1$ ratio $=1.28 \pm 0.03 ; n=$ 12). This difference was not a consequence of differences in the amplitude of the EPSCs recorded from the two populations of cells (Fig. 1C) and was observed at all three of the interstimulus intervals tested (Fig. 1D).

We also examined whether the excitatory synapses on the two cell types differ in their response to brief bursts of presynaptic stimuli. The normal firing pattern of many neurons in the CNS consists of brief bursts of action potentials (Ranck, 1973; O'Keefe, 1976; Wilson and McNaughton, 1993), which can cause synaptic responses that either facilitate or depress. Differences in this dynamic response of synapses to presynaptic bursts likely have important functional consequences for how a network processes incoming information (Buonomano and Merzenich, 1995; Markram et al., 1998). Consistent with the results from the paired-pulse experiments, excitatory synapses on DA cells displayed a depression in reponse to 10 stimuli given at $25 \mathrm{~Hz}$ (Fig. 2A,B, left panels). In contrast, excitatory synapses on GABA cells displayed a facilitation in response to the same stimulation (Fig. 2A,B, right panels). Similar results were obtained when synapses were stimulated at 40 or $100 \mathrm{~Hz}(n=3$ or 4 cells in each group; data not shown).

\section{Relative contribution of AMPA adn NMDa receptors to} EPSCs in DA and GABA cells

It is now well established that many excitatory synapses in the mammalian brain express both AMPA receptors (AMPARs) and NMDA receptors (NMDARs) but that the relative contribution of these receptor subtypes at individual synapses can vary widely (Malenka and Nicoll, 1997; Rao and Craig, 1997; Gomperts et al., 1998; Nusser et al., 1998; Liao e al., 1999; Petralia et al., 1999). Given the critical importance of NMDARs both in controlling the firing pattern of neurons in response to afferent inputs and in triggering synaptic plasticity, an important question is whether excitatory synapses on DA and GABA cells in the VTA express the same proportion of synaptic AMPARs and NMDARs. To compare the relative contribution of AMPARs and NMDARs with the EPSCs recorded from DA and GABA cells, we held cells at $+40 \mathrm{mV}$ and then applied the NMDAR antagonist D-APV (50 $\mu \mathrm{M})$. The average AMPAR-mediated EPSC (AMPAR EPSC) was obtained by averaging 20-40 responses taken after the effect of D-APV had stabilized. This average AMPAR EPSC was subtracted from the average control EPSC (in the absence of D-APV) to obtain the average NMDAR EPSC. Then the AMPAR/ NMDAR ratio was calculated by dividing the peak amplitude of the average AMPAR EPSC by the peak amplitude of the average NMDAR EPSC (Hsia et al., 1998). Consistent with previous work (Mereu et al., 1991; Johnson and North, 1992; White, 1996; Overton and Clark, 1997; Steffensen et al., 1998), EPSCs recorded from both DA and GABA cells had components mediated by both AMPARs and NMDARs, and the evoked synaptic current was blocked completely by the application of D-APV $(50 \mu \mathrm{M})$ with the AMPAR antagonist CNQX $(10 \mu \mathrm{M})($ Fig. 3A). However, there was no significant difference in the AMPAR/NMDAR ratio for these two cell types (DA cells, $0.74 \pm 0.1, n=7$; GABA cells, $0.68 \pm 0.1, n=8 ; p>0.05$ ) (Fig. $3 B$ ).

\section{Comparison of presynaptic modulation of excitatory synaptic transmission at DA and GABA cells}

The presynaptic depression of transmitter release at excitatory synapses by a wide variety of neurotransmitters is a ubiquitous mechanism of modulating synaptic strength that has been characterized extensively in a number of structures, most notably the hippocampus (Thompson et al., 1993; Miller, 1998). However, the actions of only a very limited number of neurotransmitter receptor agonists on excitatory synaptic transmission in the VTA have
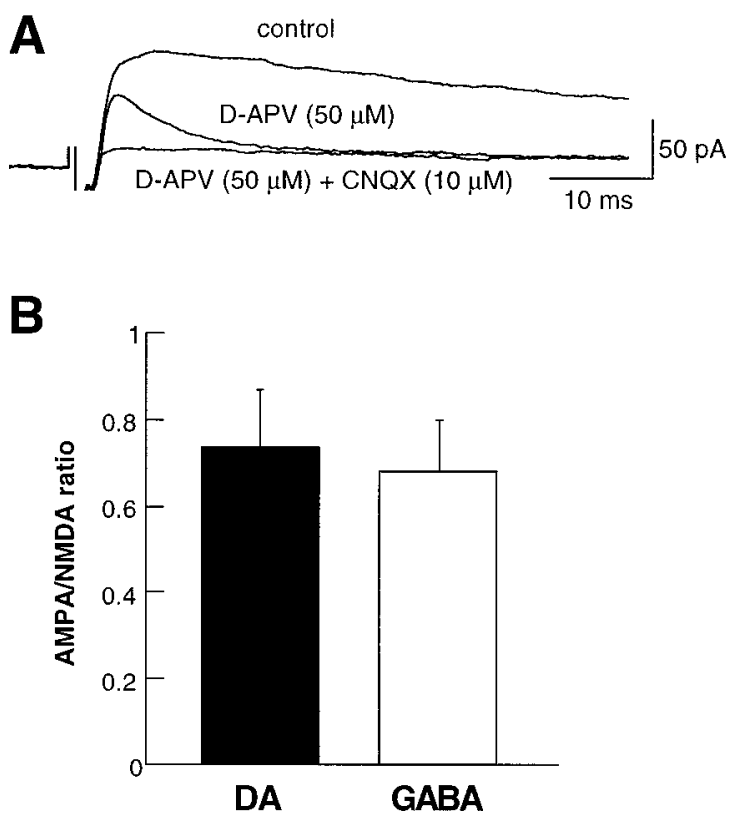

Figure 3. EPSCs recorded from DA and GABA neurons express a similar AMPA/NMDA ratio. $A$, Sample EPSCs recorded from a DA neuron under control conditions, in the presence of D-APV $(50 \mu \mathrm{M})$, and in the presence of D-APV $(50 \mu \mathrm{M})$ plus CNQX $(10 \mu \mathrm{M})$. (Each trace is an average of 20 consecutive sweeps.) $B$, Summary graph of the AMPA/ NMDA ratio for DA $(n=7)$ and GABA $(n=8)$ neurons. 

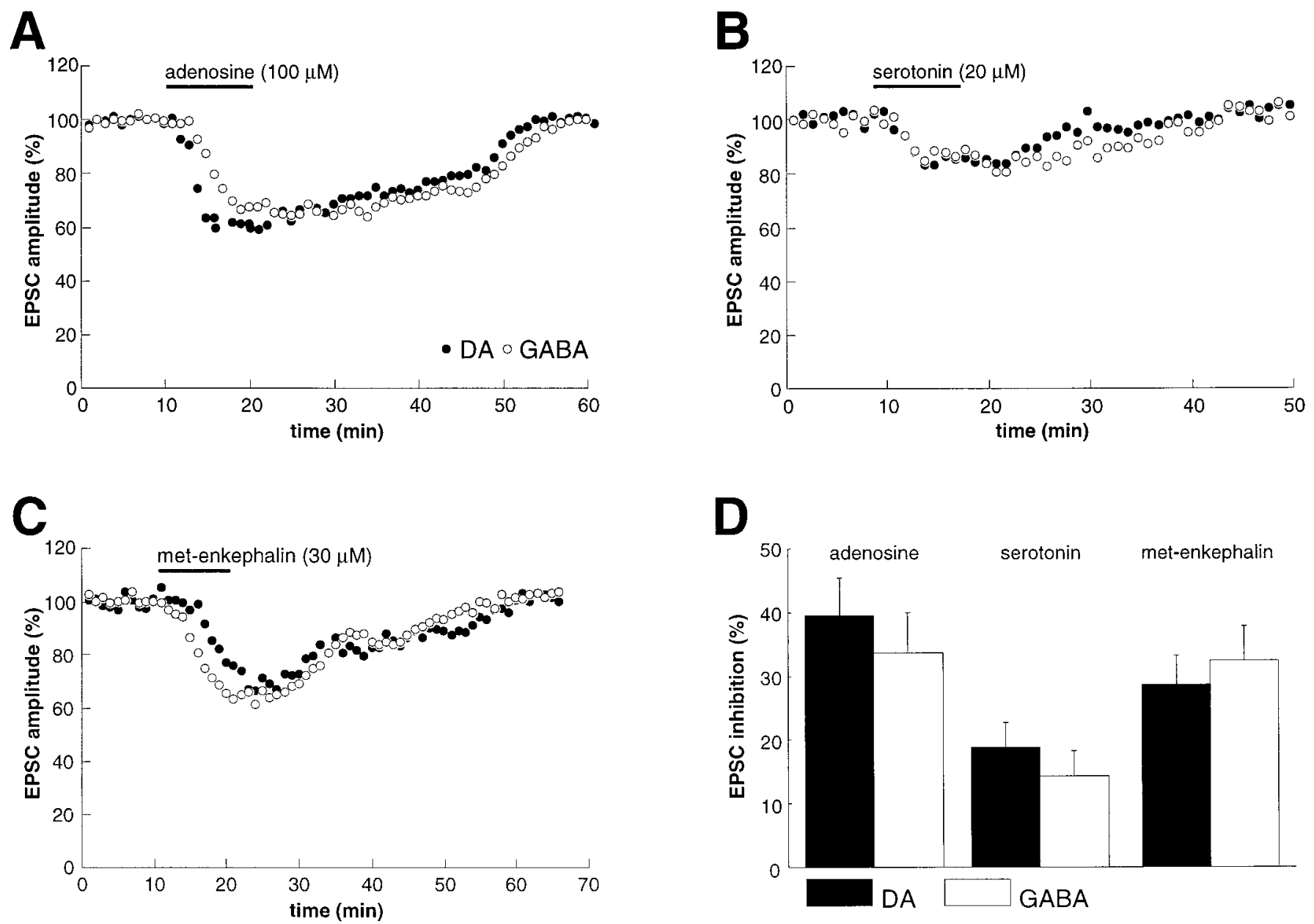

Figure 4. The magnitude of depression of EPSCs caused by adenosine, serotonin, and met-enkephalin is similar in DA and GABA neurons. $A$, Graph shows examples of the effects of adenosine $(100 \mu \mathrm{M})$ in a DA $(\bullet)$ and GABA $(\bigcirc)$ neuron. $B$, Examples of the effects of serotonin $(20 \mu \mathrm{M})$ in a DA $(\bullet)$ and GABA $(\bigcirc)$ neuron. $C$, Examples of the effects of met-enkephalin $(30 \mu \mathrm{M})$ in a DA $(\bullet)$ and GABA $(\bigcirc)$ neuron. $D$, Summary of the effects on EPSCs of adenosine, serotonin, and met-enkephalin in DA and GABA neurons $(n=3$ for each column $)$.

been examined. Therefore, we performed a survey of the actions in the VTA of a number of agonists that have been found in other brain regions to depress excitatory synaptic transmission. Furthermore, because excitatory synapses formed by the same afferent on different target cells can be modulated differentially by the same receptor agonist (Scanziani et al., 1998), we compared the actions of these agonists on EPSCs recorded from both DA and GABA cells.

Adenosine, primarily acting on presynaptic A1 receptors, depresses excitatory synaptic transmission at many synaptic relays (Greene and Haas, 1991; Thompson et al., 1993; Miller, 1998). In the VTA, adenosine $(100 \mu \mathrm{M})$ reversibly depressed EPSCs recorded from both DA and GABA cells to the same extent (Fig. $4 A, D$ ) (DA cells, $39.6 \pm 6 \%$ decrease, $n=3$; GABA cells, $33.7 \pm$ $6 \%$ decrease, $n=3 ; p>0.05)$. Similarly, serotonin $(20 \mu \mathrm{M})$, a neurotransmitter that likely contributes to the behavioral actions of psychostimulants (Cunningham et al., 1996), also caused an equivalent decrease of excitatory synaptic transmission in DA and GABA cells (Fig. 4B,D) (DA cells, $18.7 \pm 4 \%, n=3$; GABA cells, $14.3 \pm 4 \%, n=3 ; p>0.05)$. We also examined the actions of met-enkephalin, because $\mu$-opioid receptor agonists have been found to depress inhibitory and excitatory synaptic transmission in other brain regions (Thompson et al., 1993; Grudt and Wil- liams, 1995; Miller, 1998). Again, met-enkephalin (30 $\mu \mathrm{M}) \mathrm{de}-$ pressed transmission at excitatory synapses on DA and GABA cells to the same extent (Fig. 4C,D) (DA cells, $28.6 \pm 5 \%, n=4$; GABA cells, $32.6 \pm 5 \%, n=3 ; p>0.05)$.

In contrast to the actions of the agonists tested thus far (adenosine, serotonin, and met-enkephalin), the $\mathrm{GABA}_{\mathrm{B}}$ receptor agonist baclofen had dramatically different effects at synapses on DA versus GABA cells. Whereas $1 \mu \mathrm{M}$ baclofen had no significant effect on EPSCs recorded from DA cells $(6.0 \pm 2 \%$ inhibition; $n=4$ ) (Fig. 5A,C), this same concentration of baclofen dramatically depressed EPSCs recorded from GABA cells $(49.9 \pm 8 \%$; $n=4$ ) (Fig. 5B,D). This large difference in the actions of baclofen was apparent at all three concentrations that were tested (Fig. 5C,D).

\section{Synaptic plasticity in DA and GABA cells}

The most extensively studied form of synaptic plasticity in the mammalian brain has been the LTP observed at excitatory synapses on CA1 pyramidal cells (Bliss and Collingridge, 1993; Malenka, 1994; Nicoll and Malenka, 1995). Surprisingly, despite the in vivo data suggesting that an LTP-like process in the VTA contributes to the development of behavioral sensitization (Karler et al., 1991; Schenk and Snow, 1994; Clark and Overton, 1998; 


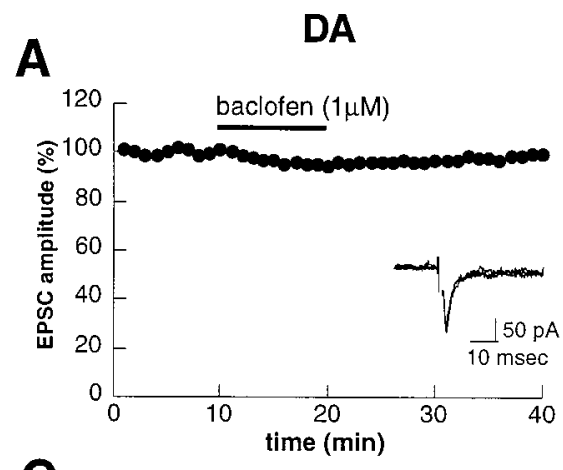

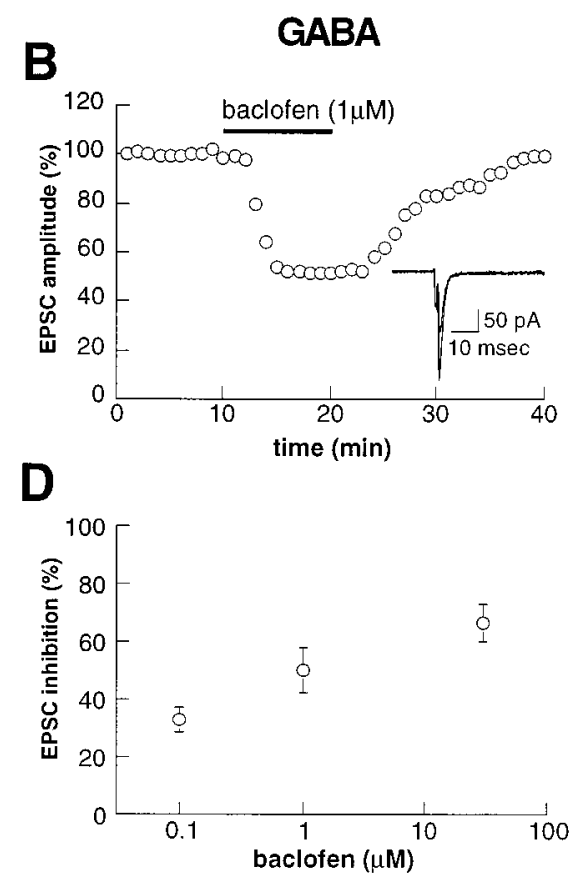

Figure 5. Baclofen depresses synaptic transmission in GABA neurons but has minimal effect on DA neurons. $A, B$, Examples of the effects of baclofen $(1 \mu \mathrm{M})$ on EPSCs recorded from a DA $(A)$ and GABA $(B)$ neuron. Baclofen caused a marked depression of EPSC amplitude in a GABA neuron while having minimal effect on the DA neuron. $C, D$, Doseresponse curves displaying the EPSC inhibition as a function of baclofen concentration for DA $(C)$ and GABA $(D)$ neurons. Each point is an average of at least four cells.
Wolf, 1998), whether or not LTP can be elicited at excitatory synapses in the VTA has not been examined. Initially, we made standard whole-cell recordings from DA cells and attempted to induce LTP by using a pairing protocol that reliably elicits LTP in hippocampal CA1 pyramidal cells (cells were held at $+10 \mathrm{mV}$ while stimulating the afferents 200 times at $1 \mathrm{~Hz}$ ). Although a stable long-lasting increase in synaptic strength occasionally could be observed after this protocol, the induction of LTP was not reliable (only 2 of 11 cells displayed a potentiation lasting $>10$ min). Because the ability to generate LTP can "wash-out" during the course of a whole-cell recording (Malinow and Tsien, 1990), we next made perforated patch recordings and applied the same pairing protocol. As shown in Figure $6 \mathrm{~A}$, this resulted in a small but stable increase in synaptic strength $(20 \pm 3 \%$ measured as the average increase in the period 30-35 min after the induction protocol; $n=6$ ) that lasted for the duration of the recording. The triggering of LTP in VTA DA cells by using perforated patch recording was fairly reliable; an increase in synaptic strength of $>10 \%$ measured 30-35 min after the induction protocol was observed in all six cells.

In contrast to the results from DA cells, when perforated patch recordings were made from GABA cells and the same pairing protocol was applied, LTP was not elicited (Fig. 6B) $(3.2 \pm 3 \%$ increase; $n=4)$. This finding is consistent with work in the hippocampus where excitatory synapses on the majority of GABAergic interneurons do not express LTP (Maccaferri and McBain, 1996).

Although the majority of excitatory synapses in the mammalian brain expresses NMDAR-dependent LTP, there are other forms of LTP for which the triggering does not require NMDARs (Johnston et al., 1992; Nicoll and Malenka, 1995). Given that the development of behavioral sensitization appears to require the activation of NMDARs in the VTA (for review, see Wolf, 1998), it was important to determine whether LTP in DA cells in VTA slices is prevented by D-APV. Because metabotropic glutamate receptors (mGluRs) also have been implicated in playing a role in hippocampal LTP (Bashir et al., 1993), we also examined the effect of the mGluR antagonist MCPG. Figure $7 A$ shows that the induction of LTP is prevented by the simultaneous application of D-APV $(50 \mu \mathrm{M})$ and MCPG $(500 \mu \mathrm{M})(1.0 \pm 11.3 \%$ increase; $n=$ $6)$. This blockade of LTP was entirely attributable to the presence of D-APV because normal LTP could be elicited when the pairing protocol was performed in the presence of MCPG alone (Fig. 7B) $(43 \pm 6.0 \%$ increase; $n=6)$. Thus these pharmacological experiments demonstrate that, like behavioral sensitization, the triggering of LTP at excitatory synapses on VTA DA cells requires the activation of NMDARs.

\section{DISCUSSION}

In vivo electrophysiological experiments have demonstrated that prefrontal cortical afferents to the VTA play an important role in controlling the firing pattern of both DA (Kalivas, 1993; White, 1996; Overton and Clark, 1997) and GABA cells (Steffensen et al., 1998). Using an in vitro VTA slice preparation, we have examined and compared some of the basic properties of excitatory synapses on these two cell populations. Several significant differences were found, including (1) the manner in which the synapses respond to repetitive presynaptic stimulation, (2) the magnitude of the depression of synaptic transmission caused by the $\mathrm{GABA}_{\mathrm{B}}$ receptor agonist baclofen, and (3) the ability to express LTP.

Before we discuss these findings, it is important to mention two limitations to the approach we have taken. First, we cannot identify definitively the source of the excitatory afferents that we stimulated in the slice preparation. We have assumed that the majority of these comes from prefrontal cortex, because this region appears to provide the major excitatory input to the VTA (Kalivas, 1993; White, 1996; Overton and Clark, 1997). Afferent projections also arise from the subthalamic nucleus and pedunculopontine region, but these have been reported to project preferentially to the substantia nigra (Scarnati et al., 1986; Christie et al., 1987; Kita and Kitai, 1987). Importantly, if stimulation of these noncortical afferents contributed to the EPSCs that we recorded, the properties of these synapses still must differ 

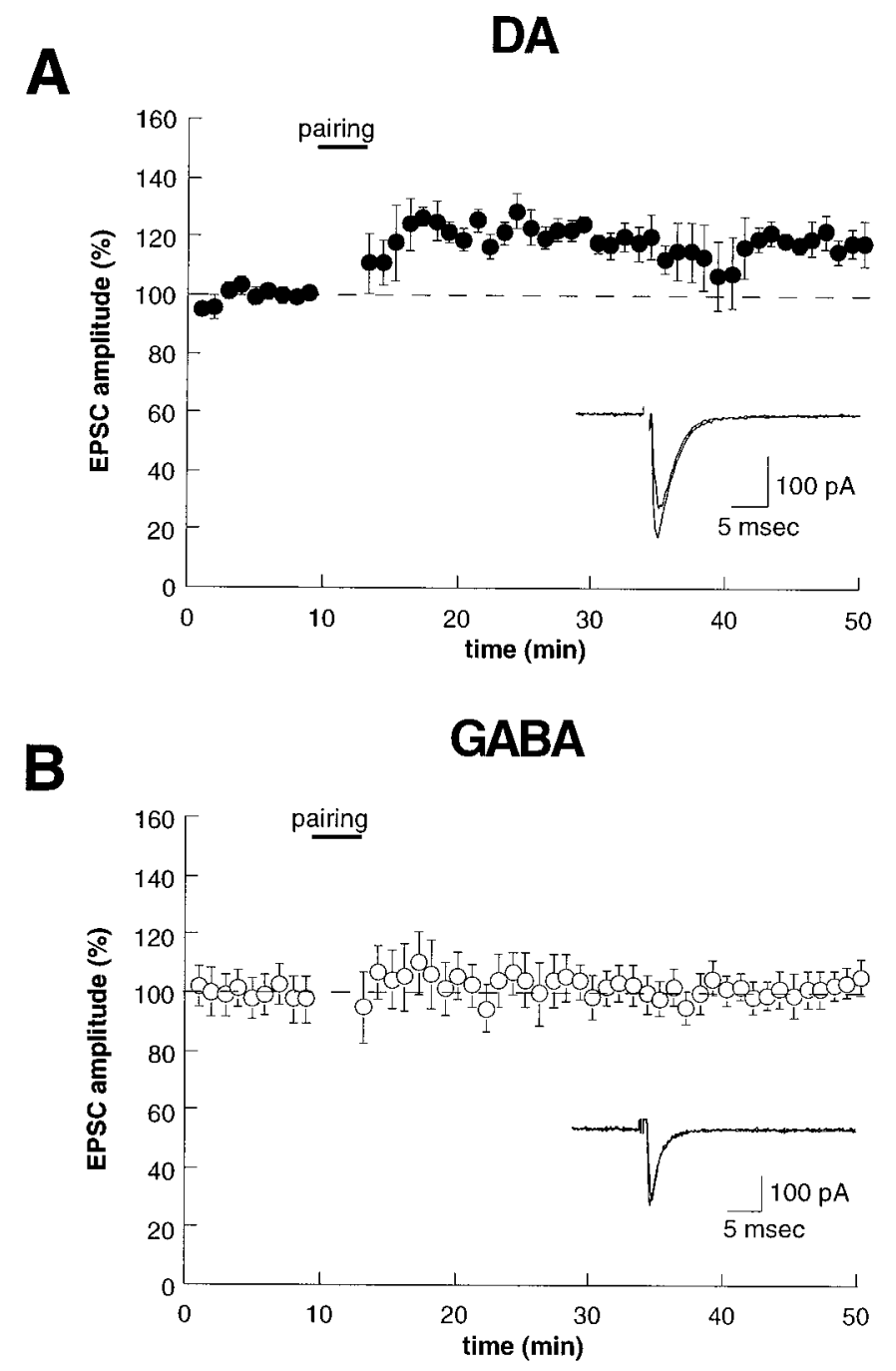

Figure 6. LTP can be elicited at excitatory synapses on DA neurons, but not on GABA neurons. $A, B$, Time course of the effects of a pairing protocol $(+10 \mathrm{mV}, 200$ stimuli at $1 \mathrm{~Hz})$ on EPSC amplitude for DA $(A$, $n=9)$ and GABA $(B, n=6)$ neurons. All recordings were made with the perforated patch-clamp recording technique.

significantly, depending on whether they are formed on DA or GABA cells. A second limitation is that we have divided our cells into two groups predominantly according to whether they expressed a prominent $I_{\mathrm{h}}$ current. This electrophysiological criterion appears warranted (Grace and Onn, 1989; Lacey et al., 1989; Johnson and North, 1992) but may have oversimplified the heterogeneity of cell types in the VTA, which may contain cells that are neither dopaminergic nor GABAergic (Cameron et al., 1997). Therefore, we cannot be certain that all cells lacking $I_{\mathrm{h}}$ were indeed GABAergic; conversely, we did not demonstrate directly that all cells expressing $I_{\mathrm{h}}$ were dopaminergic. Nonetheless, the fact that classifying the cells in this manner enabled us to demonstrate profound physiological and pharmacological differences in synaptic properties provides strong experimental evidence that validates this approach.

Recent work in slices of the hippocampus (Ali et al., 1998; Maccaferri et al., 1998; Scanziani et al., 1998) and cortex (Markram et al., 1998; Reyes et al., 1998) demonstrates that synapses made by the same axon or set of axons onto different postsynaptic targets can express profoundly different physiologi-
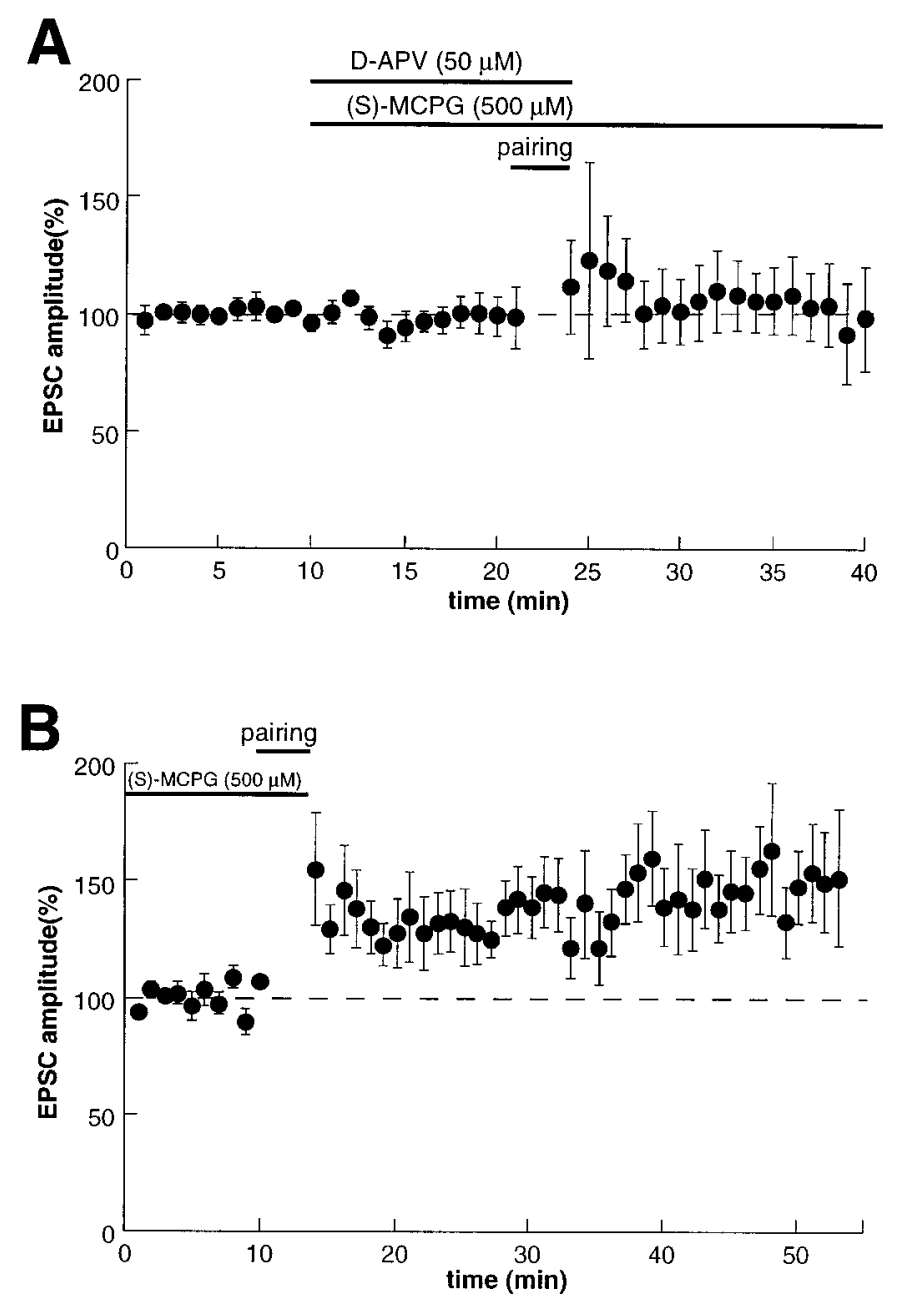

Figure 7. The triggering of LTP in DA cells requires activation of NMDA receptors, but not metabotropic glutamate receptors (mGluRs). $A$, In the presence of the NMDA receptor antagonist D-APV $(50 \mu \mathrm{M})$ and the mGluR antagonist MCPG $(500 \mu \mathrm{M})$, a pairing protocol fails to elicit LTP $(n=6)$. B, Application of MCPG $(500 \mu \mathrm{M})$ alone does not prevent LTP in DA neurons $(n=6)$.

cal properties. Similarly, we found that excitatory synapses on DA cells were depressed by paired stimuli or brief bursts of stimuli given at physiologically relevant frequencies, whereas synapses on GABA cells were facilitated in response to the same patterns of stimulation. This form of short-term modulation of synaptic strength is likely attributable to changes in presynaptic function (Zucker, 1989; Dobrunz and Stevens, 1997), and thus the differences we observed strongly suggest that fundamental properties of neurotransmitter release mechanisms differ between the excitatory synapses on DA and GABA cells in the VTA. The functional significance of this difference is unclear. If the same cell or group of cells in prefrontal cortex projects to both DA and GABA cells and these GABA cells provide feed-forward inhibition to the DA cells, the synaptic properties we have described would help significantly to limit the duration of firing of the DA cells in response to cortical activity.

We also examined the effects on excitatory synaptic transmission of a number of different neurotransmitter receptor ligands. Adenosine, serotonin, and met-enkephalin all reversibly depressed synaptic transmission to the same extent in both DA and GABA cells. To our knowledge, this is the first report of such 
actions of these neurotransmitters in the VTA. Further work will be necessary to determine the subtypes of receptors mediating these effects, their mechanism of action, and the functional consequences of this sort of synaptic modulation. In contrast to the effect of these other ligands, the $\mathrm{GABA}_{\mathrm{B}}$ receptor agonist baclofen strongly depressed synaptic transmission in GABA cells but had minimal effects on excitatory synapses on DA cells. Thus $\mathrm{GABA}_{\mathrm{B}}$ receptor agonists may provide an important tool by which excitatory inputs onto GABA cells may be manipulated independently of the inputs onto DA cells.

In terms of the role of the VTA in normal behavior and in mediating some of the behavioral changes in response to drugs of abuse, perhaps our most important finding is that excitatory synapses on DA cells can express NMDAR-dependent LTP. This provides important evidence in support of the hypothesis that the development of behavioral sensitization to psychostimulants involves an LTP-like process in the VTA (Karler et al., 1991; Schenk and Snow, 1994; Clark and Overton, 1998; Wolf, 1998). Assuming that in vivo psychostimulant administration does, in fact, elicit LTP at excitatory synapses on VTA DA cells and that this is a critical trigger for behavioral sensitization, study of the mechanisms of LTP in the VTA slice preparation will provide a tractable approach for elucidating some of the molecular changes underlying this form of behavioral plasticity.

The results presented here represent just a small portion of the data that will be necessary to develop a comprehensive model of how afferent inputs and intrinsic circuit and cellular properties interact to control the behavior of VTA neurons. Nonetheless, they provide new and useful information about some of the most basic properties of excitatory synaptic transmission in the VTA. They also provide information that will facilitate the development of pharmacological agents that can be used to probe the role of the VTA in various forms of reinforcement-dependent behavior and perhaps to prevent or alleviate the neural changes that contribute to the development of pathological states such as drug addiction.

\section{REFERENCES}

Ali AB, Deuchars J, Pawelzik H, Thomson AM (1998) CA1 pyramidal to basket and bistratified cell EPSPs: dual intracellular recordings in rat hippocampal slices. J Physiol (Lond) 507:201-217.

Bashir ZI, Bortolotto ZA, Davies CH, Berretta N, Irving AJ, Seal AJ, Henley JM, Jane DE, Watkins JC, Collingridge GL (1993) Induction of LTP in the hippocampus needs synaptic activation of glutamate metabotropic receptors. Nature 363:347-350.

Bliss TVP, Collingridge GL (1993) A synaptic model of memory: longterm potentiation in the hippocampus. Nature 361:31-39.

Buonomano DV, Merzenich MM (1995) Temporal information transformed into a spatial code by a neural network with realistic properties. Science 267:1028-1030.

Cameron DL, Williams JT (1994) Cocaine inhibits GABA release in the VTA through endogenous 5-HT. J Neurosci 14:6763-6767.

Cameron DL, Wessendorf MW, Williams JT (1997) A subset of ventral tegmental area neurons is inhibited by dopamine, 5-hydroxytryptamine, and opioids. Neuroscience 77:155-166.

Christie MJ, Bridge S, James LB, Beart PM (1985) Excitotoxin lesions suggest an aspartatergic projection from rat medial prefrontal cortex to ventral tegmental area. Brain Res 333:169-172.

Christie MJ, Summers RJ, Stephenson JA, Cook JC, Beart PM (1987) Excitatory amino acid projections to the nucleus accumbens septi in the rat: a retrograde transport study utilizing $\mathrm{D}\left[{ }^{3} \mathrm{H}\right]$ aspartate and $\left[{ }^{3} \mathrm{H}\right]$ GABA. Neuroscience 22:425-439.

Clark E, Overton PW (1998) Alterations in excitatory amino acidmediated regulation of midbrain dopaminergic neurons induced by chronic psychostimulant administration and stress: relevance to drug addiction. Addict Biol 3:109-135.

Cunningham KA, Bradberry CW, Chang AS, Reith ME (1996) The role of serotonin in the actions of psychostimulants: molecular and pharmacological analyses. Behav Brain Res 73:93-102.

Dobrunz LE, Stevens CF (1997) Heterogeneity of release probability, facilitation, and depletion at central synapses. Neuron 18:995-1008.

Gomperts SN, Rao A, Craig AM, Malenka RC, Nicoll RA (1998) Postsynaptically silent synapses in single neuron cultures. Neuron 21:1443-1451.

Grace AA, Onn SP (1989) Morphology and electrophysiological properties of immunocytochemically identified rat dopamine neurons recorded in vitro. J Neurosci 9:3463-3481.

Greene RW, Haas HL (1991) The electrophysiology of adenosine in the mammalian central nervous system. Prog Neurobiol 36:329-341.

Grudt TJ, William JT (1995) Opioid receptors and the regulation of ion conductances. Rev Neurosci 6:279-286.

Hsia AY, Malenka RC, Nicoll RA (1998) Development of excitatory circuitry in the hippocampus. J Neurophysiol 79:2013-2024.

Johnson SW, North RA (1992) Two types of neurons in the rat ventral tegmental area and their synaptic inputs. J Physiol (Lond) 450:455-468.

Johnston D, Williams S, Jaffe D, Gray R (1992) NMDA receptorindependent long-term potentiation. Annu Rev Physiol 54:489-505.

Kalivas PW (1993) Neurotransmitter regulation of dopamine neurons in the ventral tegmental area. Brain Res Rev 18:75-113.

Kalivas PW, Duffy P, Barrow J (1989) Regulation of the mesocorticolimbic dopamine system by glutamic acid receptor subtypes. J Pharmacol Exp Ther 251:378-387.

Karler R, Calder LD, Turkanis SA (1991) DNQX blockade of amphetamine behavioral sensitization. Brain Res 552:295-300.

Kita H, Kitai ST (1987) Efferent projections of the subthalamic nucleus in the rat: light and electron microscopic analysis with the PHA-L method. J Comp Neurol 260:435-452.

Koob GF, Le Moal M (1997) Drug abuse: hedonic homeostatic dysregulation. Science 278:52-58.

Lacey MG, Mercuri NB, North RA (1989) Two cell types in rat substantia nigra zona compacta distinguished by membrane properties and the actions of dopamine and opioids. J Neurosci 9:1233-1241.

Liao D, Zhang X, O'Brien R, Ehlers MD, Huganir RL (1999) Regulation of morphological postsynaptic silent synapses in developing hippocampal neurons. Nat Neurosci 2:37-43.

Maccaferri G, McBain CJ (1996) Long-term potentiation in distinct subtypes of hippocampal nonpyramidal neurons. J Neurosci 16:5334-5343.

Maccaferri G, Tóth K, McBain CJ (1998) Target-specific expression of presynaptic mossy fiber plasticity. Science 279:1368-1370.

Malenka RC (1994) Synaptic plasticity in the hippocampus: LTP and LTD. Cell 78:535-538.

Malenka RC, Nicoll RA (1997) Silent synapses speak up. Neuron 19:473-476.

Malinow R, Tsien RW (1990) Presynaptic enhancement shown by whole-cell recordings of long-term potentiation in hippocampal slices. Nature 346:177-180.

Markram H, Wang Y, Tsodyks M (1998) Differential signaling via the same axon of neocortical pyramidal neurons. Proc Natl Acad Sci USA 95:5323-5328.

Mereu G, Costa E, Armstrong DM, Vicini S (1991) Glutamate receptor subtypes mediate excitatory synaptic currents of dopamine neurons in midbrain slices. J Neurosci 11:1359-1366.

Miller RJ (1998) Presynaptic receptors. Annu Rev Pharmacol Toxicol 38:201-227.

Nicoll RA, Malenka RC (1995) Contrasting properties of two forms of LTP in the hippocampus. Nature 377:115-118.

Nusser Z, Lujan R, Laube G, Roberts JD, Molnar E, Somogyi P (1998) Cell type and pathway dependence of synaptic AMPA receptor number and variability in the hippocampus. Neuron 21:545-559.

O'Keefe J (1976) Place units in the hippocampus of the freely moving rat. Exp Neurol 51:78-109.

Overton PG, Clark D (1997) Burst firing in midbrain dopaminergic neurons. Brain Res Rev 25:312-334.

Petralia RS, Esteban JA, Wang Y-X, Partridge JG, Zhao HM, Wenthold RJ, Malinow R (1999) Selective acquisition of AMPA receptors over postnatal development suggests a molecular basis for silent synapses. Nat Neurosci 2:31-36.

Rae J, Cooper K, Gates P, Watsky M (1991) Low access resistance perforated patch recordings using amphotericin B. J Neurosci Methods $37: 15-26$.

Ranck Jr JB (1973) Studies on single neurons in dorsal hippocampal 
formation and septum in unrestrained rats. I. Behavioral correlates and firing repertoires. Exp Neurol 41:461-531.

Rao A, Craig AM (1997) Activity regulates the synaptic localization of the NMDA receptor in hippocampal neurons. Neuron 19:801-812.

Reyes A, Lujan R, Rozov A, Burnashev N, Somogyi P, Sakmann B (1998) Target-cell specific facilitation and depression in neocortical circuits. Nat Neurosci 1:279-285.

Robbins TW, Everitt BJ (1996) Neurobehavioural mechanisms of reward and motivation. Curr Opin Neurobiol 6:228-236.

Robinson TE, Berridge C (1993) The neural basis of drug craving: an incentive-sensitization theory of addiction. Brain Res Rev 18:247-291.

Scanziani M, Gahwiler BH, Charpak S (1998) Target cell-specific modulation of transmitter release at terminals from a single axon. Proc Natl Acad Sci USA 95:12004-12009.

Scarnati E, Proia A, Campana E, Pacitti C (1986) A microiontophoretic study on the nature of the putative synaptic neurotransmitter involved in the pedunculopontine-substantia nigra pars compacta excitatory pathway of the rat. Exp Brain Res 62:470-478.

Schenk S, Snow S (1994) Sensitization to cocaine's motor activating properties produced by electrical kindling of the medial prefrontal cortex but not of the hippocampus. Brain Res 659:17-22.

Schultz W (1998) Predictive reward signal of dopamine neurons. J Neurophysiol 80:1-27.

Sesack SR, Pickel VM (1992) Prefrontal cortical efferents in the rat synapse on unlabeled neuronal targets of catecholamine terminals in the nucleus accumbens septi and on dopamine neurons in the ventral tegmental area. J Comp Neurol 320:145-160.

Seutin V, Verbanck P, Massotte L, Dresse A (1990) Evidence for the presence of $N$-methyl-D-aspartate receptors in the ventral tegmental area of the rat: an electrophysiological in vitro study. Brain Res 514:147-150.

Steffensen SC, Svingos AL, Pickel VM, Henriksen SJ (1998) Electrophysiological characterization of GABAergic neurons in the ventral tegmental area. J Neurosci 18:8003-8015.

Thompson SM, Capogna M, Scanziani M (1993) Presynaptic inhibition in the hippocampus. Trends Neurosci 16:222-227.

Van Bockstaele EJ, Pickel VM (1995) GABA-containing neurons in the ventral tegmental area project to the nucleus accumbens in rat brain. Brain Res 682:215-221.

Wang T, French ED (1993) Electrophysiological evidence for the existence of NMDA and non-NMDA receptors on rat ventral tegmental dopamine neurons. Synapse 13:270-277.

Wang T, French ED (1995) NMDA, kainate, and AMPA depolarize nondopamine neurons in the rat ventral tegmentum. Brain Res Bull 36:39-43.

White FJ (1996) Synaptic regulation of mesocorticolimbic dopamine neurons. Annu Rev Neurosci 19:405-436.

Wilson MA, McNaughton BL (1993) Dynamics of the hippocampal ensemble code for space. Science 261:1055-1088.

Wise RA (1996) Neurobiology of addiction. Curr Opin Neurobiol 6:243-251.

Wolf ME (1998) The role of excitatory amino acids in behavioral sensitization to psychomotor stimulants. Prog Neurobiol 54:679-720.

Zucker RS (1989) Short-term synaptic plasticity. Annu Rev Neurosci $12: 13-31$. 